\title{
Formation of Community Security Policy in the Conditions of Decentralization as a Component of National Security of Ukraine
}

\author{
Tetiana Lushahina 1 *[0000-0001-8599-2923], Natalia Hromadska 1 [0000-0002-2310-3489], \\ Svitlana Matviienkiv 2 [0000-0002-7719-7791] \\ ${ }^{1}$ Petro Mohyla Black Sea National University, Mykolaiv, Ukraine \\ ${ }^{2}$ Vasyl Stefanyk Precarpathian National University, Ivano-Frankivsk, Ukraine \\ *t.lushagina@gmail.com
}

\begin{abstract}
The article is devoted to the study of the main perspective policies of community security in the conditions of decentralization as a component of National Security of Ukraine. It is emphasized that national security depends on the lowest level of government organization - local, namely how communities are able to implement strategic directions for the long-term development of national security independently. Certain vulnerable targets that are exposed to dangerous influences were identified. The study of security policy was carried out on the example of the communities of Southern Ukraine, as a border region, given the annexation of Crimea and the war in Eastern Ukraine with the Russian Federation. Security initiatives of Dnipropetrovsk, Zaporizhzhia, Odesa, Mykolaiv and Kherson regions in the field of community social security are considered. It is emphasized that the improvement of social protection at the community level is possible through the introduction of the program "Community Police Officer", which provides for cooperation between community members and the police, as well as increasing level of public confidence in the police. It is highlighted that a promising project in the formation of a community safety environment is the establishment and operation of Citizen Safety Centers, which provide a unified system of crisis response and ambulance services in communities. It is noted that, given the spread of COVID-19 infection, the creation of a safe environment for citizens depends on the region's ability to withstand the spread of infection (the readiness of health facilities involved in the treatment of COVID-19 patients and the citizens' willingness to participate in vaccination process to build collective community immunity). It is established that the most successful and promising in the formation of the security environment of Southern Ukraine are Dnipropetrovsk, Odesa and Kherson regions. It is paid attention to the fact that the modern policy of forming the national security of the state should be implemented from community to state on the basis of partnership, which provides for a complete reformatting of the system of providing relevant services to citizens. It is emphasized that there is the need to create conditions for cooperation between the community and the police, the community and emergency services, educational work for citizens, etc.
\end{abstract}

Keywords: security, regional security, national security, regional policy, united territorial communities, security environment, COVID-19.

\section{INTRODUCTION}

Since 2014, in Ukraine, the formation of regional and national security has played a key role in determining domestic and foreign policy. The war with the Russian Federation, the occupation of Ukrainian territories and the formation of separatist cells require completely new approaches to the formation of both national and regional security [1]. Regarding to the regional level of security, it should be emphasized that as a result of the decentralization of power, the security policy will be qualitatively changed, which will be built from the bottom up - from the community to the state. 
Therefore, this study presents the main promising policies of the united territorial communities in the field of regional security. In this context, it is necessary to define the basic concepts of the study, in particular «national security», «state security», «regional security».

Defining the concept of "security", the authors note that it is the protection of a certain existing system from the action of internal and external destructive factors. In scientific discourse, security is defined as the state of protection of life, values, interests of the subject (object) of security from threats and dangers [2]; balanced state of functioning of the social system, anthropogenic, natural systems, etc., in which a person, due to knowledge of the environment and trends in its development, is able to timely identify and minimize the negative impact of existing and potential threats or avoid them [3]; state of stable dynamic equilibrium of an object, phenomenon or process in order to preserve the basic characteristics and parameters, stability of development and functioning [4].

At the state level, national security and state security should be distinguished. The Law of Ukraine «On National Security» (2018) stipulates that «National Security of Ukraine is the protection of state sovereignty, territorial integrity, democratic constitutional order and other national interests of Ukraine from real and potential threats». The same Law defines state security as «the protection of state sovereignty, territorial integrity and democratic constitutional order and other vital national interests from real and potential threats of a non-military nature» [5].

V. Kopanchuk (2017) proposes to divide the legal framework on the issue of National Security of Ukraine into two levels:

- the first level - mandatory - the legal framework is created within the national security system (Constitution of Ukraine, laws and resolutions of the Verkhovna Rada of Ukraine, decrees and orders of the President of Ukraine, resolutions and orders of the Cabinet of Ministers of Ukraine);

- the second level - departmental - regulatory framework, which clarifies and concretizes, taking into account the specifics of each subject of national security forces, its functions and tasks [6].

At the regional level the concept of regional security is introduced. According to the Law of Ukraine «On National Security of Ukraine» (2018), the security environment at the regional level should be provided by local executive bodies and local governments within the powers defined by the Constitution and laws of Ukraine: hearing reports of officials on compliance with the law as to public security and law and order; control over the state of pre-conscription training and selection of citizens for military service, legal and social protection of citizens who are to be called up for military service, are in military service, discharged or retired, combatants and members of their families; interaction with military authorities during the planning and conduct (in the presence of civilians) of potentially dangerous activities with the participation of personnel of the Armed Forces of Ukraine, other military formations and law enforcement agencies formed in accordance with the laws of Ukraine with the use of weapons and military equipment to prevent emergencies, as well as the elimination of their consequences; informing the public about their activities in the performance of tasks related to national security and defense [5]. In order to exercise civilian control, local self-government bodies may form deputy commissions, and appropriate subdivisions may be established in local executive bodies.

Considering the security environment of the community, it is necessary to identify certain vulnerable targets that are exposed to dangerous influences: strategic goals of the community and programs for their implementation, community values and their carriers (people, youth, business, self-government, civil rights and freedoms). That is, the security environment of the community includes not only the personal security of the citizen or, for example, the local government, but is a whole system of interconnected areas of social, economic, political, informational, environmental security. After all, the security environment applies not only to the municipal police, but also to the availability of video monitoring and video surveillance facilities in the community; fire and rescue stations / teams (may belong to one community or serve several communities); programs for the development of various types of alternative energy and energy saving; the ability of the community to upgrade municipal water communications and water supply; opportunities for construction and repair of roads belonging to communities; programs for effective water supply management and quality water supply; monitoring and improving the condition of housing and communal services; availability of internet connection and community communication capacity.

In this context, it is important to study the security policy of the communities of Southern Ukraine as a border region, given the annexation of Crimea and the war in Eastern Ukraine with the Russian Federation.

\section{RESEARCH METHODOLOGY}

The study is based on statistics from official Internet resources. The data of the regional passports are compiled using the portal «Decentralization provides opportunities» [7]. Data on the implementation of the «Community Police Officer» program in selected regions 
were obtained according to the official website of the National Police of Ukraine [8]. Information on Citizens' Safety Centers is taken from the website of the Dnipropetrovsk Regional State Administration [9], Zaporizhzhia Regional State Administration [10], Mykolaiv Regional State Administration [11], Odesa Regional State Administration [12], Kherson Regional State Administration [13]. Data on health care facilities involved in the treatment of patients with COVID-19 were obtained from the official website of the National Health Service of Ukraine [14].

\section{RESEARCH RESULTS}

Given the current domestic and foreign policy conditions for the development of Ukrainian statehood, of course, the formation of a secure environment in the country is one of the most pressing issues on the agenda. We believe that national security depends on the lowest level of government organization - local. In particular, how communities are able to independently implement strategic directions for the long-term development of national security. Thus, this study reveals the extent to which the southern region of Ukraine is able to implement new initiatives to strengthen the regional security environment from community to state.

Choosing the South of Ukraine as a region, we include the following regions: Odesa, Mykolaiv, Kherson, Dnipropetrovsk, Zaporizhzhia. Due to the annexation of Crimea, we cannot consider data for this region. For comparison, we indicate the passport of each region (total area, population, amount of communities) (Table 1).

Table 1. Regions' passport of the Southern region of Ukraine*

\begin{tabular}{|c|l|l|l|l|}
\hline № & \multicolumn{1}{|c|}{ Region } & $\begin{array}{c}\text { Amount of } \\
\text { territorial } \\
\text { communities }\end{array}$ & Population & $\begin{array}{c}\text { Area } \\
\text { (thousand } \\
\text { sq. km) }\end{array}$ \\
\hline 1. & Dnipropetrovsk & 86 & 3176978 & 31914 \\
\hline 2. & Zaporizhzhia & 67 & 1682534 & 27180 \\
\hline 3. & Mykolaiv & 52 & 1119862 & 24598 \\
\hline 4. & Odesa & 91 & 2377191 & 33310 \\
\hline 5. & Kherson & 49 & 1027913 & 28461 \\
\hline
\end{tabular}

* Made according to the portal «Decentralization provides opportunities» [7]
According to the regions' passport, the largest on the area is Odesa region, and the smallest - Mykolaiv. The largest population is Dnipropetrovsk, and the smallest one is Kherson region. The largest amount of communities is in Odesa region, and the smallest is in Kherson region.

We propose to consider security initiatives of selected regions in the field of community social security. One of the directions of creating a safe social environment of the community is the reform of the National Police of Ukraine, which provides a model of community-oriented to community policing [15]. As part of this reform, starting in 2019, the Community Police Officer program was introduced in Ukraine. As of August 2021, this program was initiated in 21 regions of Ukraine, including Odesa, Mykolaiv, Kherson, Dnipropetrovsk, and Zaporizhzhia (Table 2).

Table 2. Implementation of the «Community Police Officer» program

\begin{tabular}{|l|l|c|c|}
\hline № & \multicolumn{1}{|c|}{ Region } & $\begin{array}{c}\text { Amount of } \\
\text { territorial } \\
\text { communities } \\
\text { participating in } \\
\text { the program } \\
\text { (May-August } \\
2021)\end{array}$ & $\begin{array}{c}\text { Amount of } \\
\text { territorial } \\
\text { communities } \\
\text { participating } \\
\text { in the } \\
\text { program } \\
(2018-2020)\end{array}$ \\
\hline 1. & Dnipropetrovsk & 46 & 42 \\
\hline 2. & Zaporizhzhia & 29 & 20 \\
\hline 3. & Mykolaiv & 7 & 4 \\
\hline 4. & Odesa & 32 & 0 \\
\hline 5. & Kherson & 24 & 0 \\
\hline 4. & Odesa & 32 & 0 \\
\hline 5. & Kherson & 24 & \\
\hline
\end{tabular}

Involvement of the community in the formation of a safe social environment is manifested in the creation and operation of Citizens' Safety Centers - another promising project that radically changes approaches to ensuring social security of citizens. Dnipropetrovsk, Kherson and Odesa regions joined the project (Figure 1). The Center has a fire brigade, an ambulance station and an office of a district police officer. There is also a single dispatch service, which was created to coordinate the work of the fire and rescue unit, addressing police calls, medical care (Table 3 ). 
In the context of the spread of COVID-19 [16-18] infection, the question of the readiness of medical institutions in the region to create a safe environment for citizens, as well as the willingness of citizens to participate in the vaccination process to create a collective immunity of communities is important.

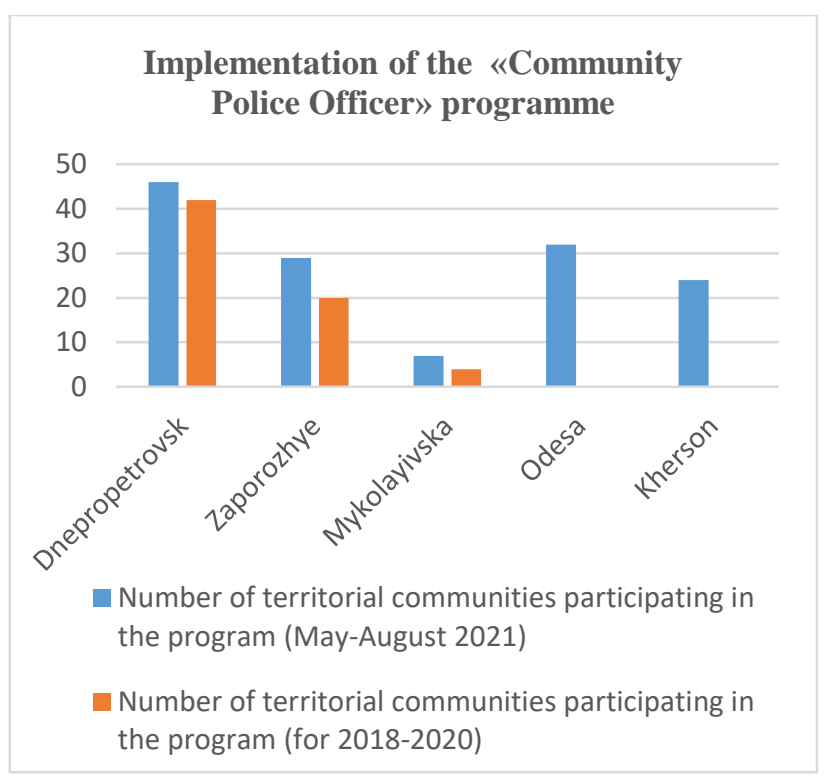

Figure 1 Amount of territorial communities of Southern Ukraine participating in the «Community Police Officer» program's implementation

Table 3. Citizen safety centers*

\begin{tabular}{|c|l|c|c|}
\hline № & \multicolumn{1}{|c|}{ Region } & $\begin{array}{c}\text { Amount of } \\
\text { territorial } \\
\text { communities }\end{array}$ & $\begin{array}{c}\text { Amount } \\
\text { of centers }\end{array}$ \\
\hline 1. & Dnipropetrovsk & 86 & 3 \\
\hline 2. & Zaporizhzhia & 67 & 0 \\
\hline 3. & Mykolaiv & 52 & 0 \\
\hline 4. & Odesa & 91 & 1 \\
\hline 5. & Kherson & 49 & 1 \\
\hline
\end{tabular}

*The information is taken from the official websites of these regional state administrations

According to the National Health Service of Ukraine, we have the following indicators (Table 4):
Table 4. Health facilities involved in the treatment of patients with COVID-19

\begin{tabular}{|c|c|c|c|c|c|}
\hline № & Region & 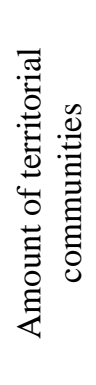 & 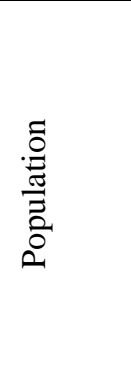 & 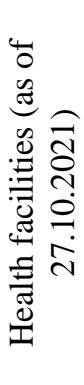 & 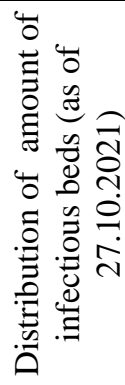 \\
\hline 1. & Dnipropetrovsk & 86 & 3176978 & 22 & 3180 \\
\hline 2. & Zaporizhzhia & 67 & 1682534 & 11 & 1862 \\
\hline 3. & Mykolaiv & 52 & 1119862 & 9 & 2745 \\
\hline 4. & Odesa & 91 & 2377191 & 13 & 2190 \\
\hline 5. & Kherson & 49 & 1027913 & 6 & 896 \\
\hline
\end{tabular}

\section{DISCUSSION OF RESULTS}

Social protection of the population at the community level was to be improved through the introduction of the «Community Police Officer» program, which provided for the solution of security problems of a specific united territorial community. A community police officer - a community resident who is interested in the development of his community and focused on the needs of the local population, must maintain constant contact with residents. He should perform the functions not only of the sheriff, but also actively participate in the implementation of public security projects together with the community, conduct inspections of citizens' appeals and take the necessary measures. The project envisages the creation of police stations, a change in approaches to public services.

Dnipropetrovsk region is one of the first regions, which took part in this project and successfully implemented it in 46 united territorial communities. However, the project is being actively implemented today and if in 2020 neither Odesa nor Kherson regions were involved in the project, now the Project is being actively implemented in these regions. The main goal of the «Community Police Officer» program is the cooperation of community members and the police, as well as increasing the level of public confidence in the police.

Another promising project in the formation of a community safety environment is the creation of a network of Citizen Safety Centers. So far, the project is being successfully implemented in three regions of Southern Ukraine (Dnipropetrovsk, Odesa and Kherson) and is expected to expand to other regions. The most successful in the project is Dnipropetrovsk region. Such Citizen Safety 
Centers provide a unified system for responding to crisis services and providing emergency care in communities.

The current situation in the field of health care is one of the key issues of its functioning in the communities determines the ability of the region to withstand the fight against the spread of COVID-19 infection. Each region calculates the maximum possible amount of necessary health care facilities involved in the treatment of patients with COVID-19. Thus, the largest amount of relevant institutions is identified in the Dnipropetrovsk region, and the smallest in the Kherson region.

Therefore, the security environment of communities depends on the perception of community members' possibility of exercising their primary rights and forming a sense of security in the community, which involves a complete reformatting of the system of providing relevant services to citizens. The point is that it is necessary to create conditions for cooperation between the community and the police, the community and emergency services, to conduct educational work for citizens, and so on. From the above data we see that the most successful and promising in the

\section{REFERENCES}

[1] Kovalchuk, T.I. Korystin, O.Y. and Sviridyuk, N.P. (2019), "Hybrid threats in the civil security sector in Ukraine", Problems of Legality, vol. 147, pp. 163175, DOI: 10.21564/2414-990x.147.180550

[2] Pasichnyk, V. (2011), "Philosophical category of security as the basis of a new paradigm of state management of national security", Demokratychne vriaduvannia, vol. 7, available at: http://nbuv.gov.ua/UJRN/DeVr_2011_7_7.

[3] Korzh, I. (2019), "Security: methodological approaches to the concept", Nacional'nyj juridicheskij zhurnal: teorija i praktika, vol. 4 (38), available

at: http://www.jurnaluljuridic.in.ua/archive/2019/4/part _1/4-1.pdf

[4] Nazarova, H. \& Demianenko, A. (2018), "Theoretical aspects of defining the essence of the concept "security", Materialy Mizhnar. nauk.-prakt. konf. [Ekonomichnyi rozvytok i spadshchyna Semena Kuznetsia], KhNUE, Ukraina, pp. 109-110.

[5] On national security (2018), Law of Ukraine № 2469VIII. (2018, June 21), Vidomosti Verkhovnoi Rady, vol. 31, st. 241.

[6] Kopanchuk, V. (2017), "Regulatory and legal support of the state policy of national security and public order of Ukraine", Derzhavne upravlinnia: formation of the security environment of Southern Ukraine are Dnipropetrovsk, Odesa and Kherson regions.

\section{CONCLUSIONS}

Thus, the current policy of national security should be implemented from community to state on the basis of partnership with the state, and this involves reforming the police system and forming a staff of sheriffs (community police officers) who will cooperate with citizens, which should significantly increase citizens' trust to the police institute in Ukraine.

In rural communities, when there is a lack of funds for the maintenance of certain health care facilities, police and fire safety stations, the program of Citizen Safety Centers, which combines all these services, is successful. In the long-term plan of security development of the Southern region of Ukraine it is necessary to pay attention to possible optimization projects for the provision of quality services to citizens in the field of both social security and other areas, which may be a prospect for further research.

udoskonalennia ta rozvytok, vol. 12, available at: http://www.dy.nayka.com.ua/?op=1\&z=1610

[7] Decentralization provides opportunities, available at: https://decentralization.gov.ua/state?sort_direction= \&sort_by)

[8] National Police of Ukraine, available at: https://www.npu.gov.ua/

[9] Dnipropetrovsk Regional State Administration, available at: https://adm.dp.gov.ua/

[10] Zaporizhzhia Regional State Administration, available at: https://www.zoda.gov.ua/ [

[11] Mykolaiv Regional State Administration, available at: https://www.mk.gov.ua/

[12] Odesa Regional State Administration, available at: https://oda.odessa.gov.ua/

[13] Kherson Regional State Administration, available at: https://khoda.gov.ua/

[14] National Health Service of Ukraine, available at: https://nszu.gov.ua/

[15] Shadska, U. (2018), Community security: finding common solutions, «HUSS», Kyiv, Ukraina, available at: https://decentralization.gov.ua/uploads/library/file/3 50/Bezpeka_Hromad.pdf

[16] Anurag, Tatkare Hemangi, Patil Tejal, Salunke Shreya, Warang and Dipak, Marathe (2021), 
"COVID-19 Patient Health Monitoring System ", International Journal of Engineering and Manufacturing (IJEM), vol.11, no. 5, pp. 48-55. DOI: $10.5815 /$ ijem.2021.05.05

[17] Ahmed Hassan Mohammed Hassan, Arfan Ali Mohammed Qasem, Walaa Faisal Mohammed Abdalla and Omer H. Elhassan (2021), "Visualization \& Prediction of COVID-19 Future Outbreak by Using Machine Learning", International Journal of Information Technology and Computer Science (IJITCS), vol. 13, no. 3, pp.16-32. DOI: $10.5815 /$ ijitcs.2021.03.02

[18] Mirza Waseem Hussain, Tabasum Mirza, Malik Mubasher Hassan (2020) "Impact of COVID-19 Pandemic on the Human Behavior", International Journal of Education and Management Engineering (IJEME), vol. 10, no. 5, pp. 35-61. DOI: $10.5815 /$ ijeme.2020.05.05 